\title{
Irregular auxiliaries after 1945
}

\author{
Sibylle Scheipers
}

\author{
Author contact details: \\ Dr Sibylle Scheipers \\ Senior Lecturer in International Relations \\ University of St Andrews \\ Arts Building \\ The Scores \\ St Andrews KY16 9AX \\ United Kingdom \\ ss203@st-andrews.ac.uk
}

\begin{abstract}
Collaboration with native auxiliaries in wars in the peripheries of the international system is an age-old practice, the relevance of which is likely to increase in the twenty-first century. Yet, the parameters of such collaboration are understudied. This article aims to contribute to the nascent yet fragmentary scholarship on the use of native auxiliaries. It identifies three intellectual templates of the collaboration between western regular forces and native auxiliaries: the eighteenth century model of auxiliary 'partisans' as tactical complements to regular armed forces; the nineteenth century transformation of the 'partisan' into the irregular guerrilla fighter and the concomitant rise of the 'martial races' discourse; and, finally, the post-1945 model of the loyalist auxiliary as a symbol of the political legitimacy of the counter-insurgent side in wars of decolonization and post-colonial insurgencies. The article focuses on the rise of loyalism after 1945 in particular, a phenomenon that it seeks to understand within the broader context of irregular warfare and the moral reappraisal of irregular fighters after the Second World War.
\end{abstract}

Keywords: colonial war, wars of decolonization, auxiliaries, Malaya, Kenya, Vietnam, Algeria

Native auxiliaries in counter-insurgency campaigns and colonial warfare are an understudied topic, in spite of their central relevance to western warfare in the peripheries of the international system. ${ }^{1}$ There are only a handful of scholarly articles available on this topic, a number of which remain at the surface of the debate by focusing solely on the tactical and operational potentials and pitfalls of the use of 
native auxiliaries. ${ }^{2}$ Few take into account the broader strategic, political, moral and legal implications of cooperating with such forces. ${ }^{3}$

This lack of scholarship is both surprising and worrying when viewed against the background of recent and current military conflicts. Afghanistan, Iraq, Libya and again Iraq/Syria, but also Russia's reliance on separatist rebels in eastern Ukraine, have demonstrated that the cooperation between western military forces and native auxiliaries is likely to play a dominant role, at least in the near future. Yet western strategic thinking on the ways in which native auxiliaries can be integrated into military operations, how they can be supported and trained if necessary, remains poor. There is little understanding of the different models and templates of the structure and organization of such collaboration, with the result that the way in which auxiliaries are employed has often unintended, if to some extent foreseeable, consequences. ${ }^{4}$

This article aims to reinvigorate the nascent, yet still highly fragmentary debate on native auxiliaries by investigating the historical trajectory of the relationship between regular forces and local fighters. It outlines three intellectual templates of their collaboration, which roughly correspond to three different historical phases, though the boundaries between these phases are not clear-cut, and earlier templates often survived into, or were revived during, later phases. The first template is the eighteenth century model of the native auxiliary as an ethnic irregular fighter and tactical complement to regular armed forces. Historically, these fighters were called 'partisans'. The second template covers the marginalization of 'partisans' as illegitimate combatants and their concomitant, yet paradoxical reinvention in the form of 'martial races'. The latter formed the core of late nineteenth and early twentieth century colonial armies, which became increasingly regularized and integrated into the European military command structures. The third template consists of the rise of native loyalist auxiliaries after 1945. Loyalism in this context is not to be understood as a description of the 'true' motives of the auxiliaries in question. Rather, 'loyalism' functioned as a strategic and political narrative that constructed a specific relationship between sponsors and auxiliaries. This narrative could be manipulated by both sides to a certain extent - auxiliaries could pursue their own agendas under the guise of 'loyalism', just as well as sponsors could promote or drop 'loyalist' auxiliaries for opportunistic motives. Nonetheless, the narrative of loyalism provided certain 
constraints on legitimate behavior by both sides, as we shall see. For instance, if particular auxiliaries were evidently coerced into supporting their sponsors' military efforts, sponsors usually refrained from trying to depict them as 'loyalists', since such an effort would have lacked credibility.

The rise of loyalist auxiliaries represents a departure from the earlier trend towards the increasing regularization of colonial troops. They were deliberately set apart from regular armed forces and often stayed outside of the regular military command structures. Their military effectiveness was limited as a result of poor training and armament. In fact, the main motive for their recruitment was political rather than military, in that they were designed as symbol of legitimacy of western political power in the peripheries of the international system after 1945.

These three intellectual templates help us understand and categorize patterns in which native auxiliaries were used in the past and today. While the transformation around 1800 from 'partisans' to 'guerrilla fighters' has received some attention over the past few years, much less has been written about the rise of loyalism after $1945 .^{5}$ This is the area that this article will focus on in particular. Its main argument is that the Second World War led to a moral reappraisal of the role of irregular fighters in that it epitomized the lesson that as resistance fighters against Nazi German and Imperial Japanese occupation, they could be morally vindicated. Indeed, in the context of colonial and post-colonial wars after 1945, to the extent that they could be harnessed to the political agendas of colonial powers or their successors as loyalist auxiliaries, they could become the foundation of claims to political legitimacy on the part of the imperial powers in these conflicts.

The historical evolution of military auxiliaries makes it inherently difficult to define them. Nonetheless a definition is needed. For the purpose of this paper, military auxiliaries are defined as military forces that support the military efforts of regular armed forces of a state. They are hence distinct from regular armies. At the same time, they are distinct from proxies, which are defined as receiving merely indirect support from third parties with the aim of furthering the latter's strategic interest. $^{6}$ 
The remainder of this article proceeds in four steps: the next section presents a brief outline of the history of the native auxiliary fighter from around 1750 to 1945 , hence covering both the first and the second intellectual template mentioned above. The second part is devoted to the rise of loyalist auxiliaries in the wars of decolonization. The third section will evaluate the rise of loyalism in the context of the history of irregular warfare after 1945. The conclusion will summarize the argument and explore its relevance for the context of wars in the twenty-first century.

\section{The transformation of the partisan, 1750-1945}

The practice of relying on military auxiliaries is as old as warfare itself. However, it was only when European armed forces became increasingly 'regularized' that military auxiliaries were referred to as actors different from regular armed forces. By the eighteenth century monarchs in Europe had successfully increased their control over their armies. However, paradoxically it had become increasingly difficult for them to use those armies to wage war. The average size of European armies had more than doubled between the mid-seventeenth and the early eighteenth centuries. Mobilizing for major war slowed down economic production and inevitably put a strain on state finances. Communication capabilities had not grown in equal measure as the size of armies, hence limiting the radius of their campaigns. Tactical limitations meant that battles were often costly, but rarely decisive. ${ }^{7}$ In these circumstances reliance on small mobile units of light infantry and light cavalry provided European states with increased room for manoeuvre. These units could either serve alongside regular units and take on tasks that regular forces struggled with, such as reconnaissance, or they could operate independently. ${ }^{8}$ They were something akin to early modern Special Forces. ${ }^{9}$ The names of these units often reflected their ethnic origin: the Habsburg empire relied on 'Pandours' and 'Croats' who stemmed from the border region with the Ottoman empire, Russia used 'Cossacks' and Bavaria and Prussia 'Hussars'. The overall notion for these light infantry and cavalry detachments was 'parties' in French or 'Partheyen' in German. Their members were called 'partisans'. ${ }^{10}$

While these practices originated in Europe, they were soon applied in colonial warfare. During the French and Indian War (1754-63) both France and Britain 
recruited Native American auxiliaries to support their own forces. This was, of course, a common practice in colonial warfare. However, in the French and Indian War contemporaries perceived native auxiliaries not only as a supplement to their own forces. Rather, they saw them as a decisive asset. British commander-in-chief Lord Loudoun remarked in 1756 that 'Whoever is Superior in irregulars [Native American auxiliaries] has an infinite advantage over the other side; and must greatly weaken, if not totally destroy them before they can get to the Point where they can make their Push. ${ }^{11}$

The turn of the eighteenth to the nineteenth century was a 'watershed' moment for the European 'partisan' auxiliaries. The notion of the 'partisan' was subject to a fundamental transformation. ${ }^{12}$ With the French Revolution and the concomitant nationalization of war in Europe, the term 'partisan' came to designate counterrevolutionary rebels. The tactical meaning of la petite guerre gave way to the notion of people's war or guerrilla warfare - two terms that were burdened with issues of political legitimacy. The denunciation of 'partisans' and guerrilla fighters was based on a complex interplay of perceptions that included claims that their way of fighting was abhorrent, that they were fighting for the wrong motives and that they had no right to take up arms. At first glance, this transformative process was paradoxical: after all, with the nationalization of war even regular warfare had to a certain extent evolved into 'people's war'. The rhetoric of the French Revolution depicted the Army of the French Revolution as the 'nation in arms' rushing to the defence of the fatherland. If the counter-revolutionary rebels in the Vendée and the guerrilla fighters in the Peninsular War, to name but two examples from the era of the French Revolutionary and Napoleonic Wars, were also claiming to fight on behalf of the 'people' (if not necessarily the 'nation') it was difficult to see why they were less legitimate than the 'nation in arms'. Yet, it was precisely this ambiguity with respect to the intellectual roots of both the nationalization of European armed forces and popular uprisings against the authority of the nation state (or the occupation forces of another state) that made the condemnation of rebels and guerrillas necessary. ${ }^{13}$

The marginalization of irregular fighters and their denunciation as illegitimate combatants remained the defining theme of warfare in both Europe and North America throughout the nineteenth century. Although European powers had hoped 
that the issue of people's war had been an aberration to which the era of restoration after 1815 had put a definitive end, people's war cropped up again in the German wars of unification in the second half of the nineteenth century, specifically in the French mobilization of so-called 'francs-tireurs' during the Franco-Prussian War (1870-71). On the other side of the Atlantic, too, the American Civil War (1861-65) highlighted the extent to which the question of who was a legitimate combatant was bound up with conflicts of political ideology that were at the heart of the causes for the war itself. The perception of deep divergences was at the core of nascent efforts to codify the law of armed conflict such as the Lieber Code and the 1874 Brussels project. Owing precisely to the deep rifts in contemporary views on lawful combatancy, it took about four more decades until these efforts came to fruition in the shape of the 1907 Hague convention on land warfare. The convention bears the mark of the interest of large land powers such as Imperial Germany and Russia in keeping the definition of lawful combatants as closely tied to the idea of a professional land army as possible.

Developments in the colonies in the nineteenth century ran parallel to these debates in Europe and North America. Colonial powers had at all times relied on local auxiliaries recruited from within their colonial territories or from nearby localities. In the second half of the nineteenth century all colonial powers regularized their irregular colonial auxiliaries to a certain extent. France recruited tirailleurs, colonial light infantry troops that were deployed both in the colonies and in European theatres of war. Britain and Germany followed the French example by transforming their semi-private colonial auxiliaries such as the East India Company and the WissmannTruppe into (semi-)regular colonial forces. Several factors played a role in that transformation. In the case of Britain, the 1857 mutiny of the Bengal Army drove home the message that the pragmatic and straightforward recruitment of local auxiliaries into colonial forces was fraught with difficulties. According to Gavin Rand, native auxiliaries were 'at once the pre-eminent institution of the imperial state and its greatest threat'. ${ }^{14}$ The experience of the 1857 mutiny and the predicament of recruiting native auxiliaries that it highlighted prompted the evolution of the concept of 'martial races'. The notion of 'martial races' was based on the idea that some social and 'ethnic' groups in India (and elsewhere) were biologically or culturally more disposed to make effective and loyal soldiers than others. In the colonial context, 
therefore, the eighteenth century tradition of using military auxiliaries as tactical complements to regular forces was replaced with racial theories on the 'correct' way of recruiting colonial auxiliaries. ${ }^{15}$

The rise of the 'martial races' discourse in the context of colonial warfare was to a certain extent the flipside of the marginalization of irregular fighters in Europe. Characteristically, European imperialists approached their colonial auxiliaries with in the framework of an 'orientalist' perspective. Non-European fighters were assigned both attributes of inferiority and superiority. ${ }^{16}$ They were seen as inferior, because they were regarded as 'savage', 'uncivilized' and potentially 'undisciplined'. At the same time, their negative attributes were perceived as an advantage: 'uncivilized' behaviour could translate into increased martial spirits and fighting prowess, 'childish' traits of character could translate into overwhelming loyalty to their commanding officers and steadfastness under fire. At the same time, the "martial races' discourse displayed some similarities with its eighteenth century predecessors: after all, eighteenth century light infantry and cavalry units had traditionally been recruited from among ethnic groups on the borders of Europe. ${ }^{17}$ However, the 'cult of the regular' and the marginalization of the irregular was an intellectual template that exerted its influence beyond the boundaries of Europe. The drive towards creating regular colonial armies could be observed among all imperial powers at the end of the nineteenth century.

A further factor for the increasing regularization of colonial auxiliary troops came with the First World War and the realization of the manpower demands of industrialized mass warfare. France pioneered this development. While it had already deployed North African tirailleurs units in the Crimean War and in the FrancoPrussian War, it was only during the last two-and-a-half years of the First World War that France massively relied on colonial troops from West Africa. In sum, it conscripted 140,000 West African troops into the French Army and deployed them on the western front. The French approach was inspired by a racial ideology that was similar to the British idea of 'martial races' in that it emphasized the characteristics of physical vigour, bravery and loyalty in colonial troops. At the same time, advocates of the mass recruitment of West African soldiers such as General Charles Mangin attributed traits to what he called 'la force noire' that seemed to make them 
particularly suited to industrialized warfare in Europe: 'the absence of nervousness and an incomparable power of shock. Their arrival on the battlefield would have a considerable moral effect on the adversary. ${ }^{18}$ In other words - and this is another parallel to the eighteenth century theoretical origins of the use of auxiliaries - colonial troops were not merely supposed to augment European manpower. Rather, their advocates saw in them a possible solution to the tactical predicaments of the modern European battlefield.

With increasing regularization, auxiliaries lost their irregular character and were transformed into members of the regular armed forces of their sponsor countries. However, this did not necessarily mean that their opponents treated them as they would have treated their metropolitan comrades, as widespread massacres committed on captured French colonial troops by Nazi German forces in 1940 illustrate. ${ }^{19}$

\section{Insurgencies after 1945: the rise of loyalist auxiliaries}

Colonial and 'post'-colonial insurgencies after the Second World War are characterized by a complex coexistence and cooperation of different military forces. Regularized colonial troops that had their roots in the 'martial races' era fought alongside metropolitan units and allied foreign military forces. At the same time, western powers also started recruiting a new category of local irregular auxiliaries, whose main value was mostly not seen in their military contribution, but in their political impact on the conflict dynamic: these auxiliaries, though ostensibly recruited for military purposes, were raised as a conspicuous sign of loyalism among the native population. The following section will consider the emergence of loyalist auxiliaries in Indochina, Malaya, Kenya, Algeria, Vietnam and Dhofar. This list of historical instances of the use of loyalist auxiliaries is not exhaustive (loyalist militias were also raised in Brunei and Borneo, for instance ${ }^{20}$, but provides a sufficiently large crosssection of well-researched and well-documented cases to explore their characteristic features. ${ }^{21}$

In Indochina (1946-54) the principal regular and quasi-regular forces that France deployed were organized in the Corps Expéditionnaire Français en ExtrêmeOrient (CEFEO). CEFEO consisted of troops from the French Foreign Legion plus 
colonial forces including former members of the tirailleurs tonkinois and tirailleurs annamites, but also French colonial troops from North Africa. After France's recognition of Vietnam as an independent state in the 1949 Élysée accords, the emperor Bao Dai raised the regular Vietnamese National Army, which also fought against the Viet Minh forces. Early on in the campaign both France and Britain had successfully enlisted existing 'private armies' of criminal networks and religious sects such as the Binh Xuyen, Hoa Hao and Cao Dai into the fight against the Viet Minh. In 1949 these were also absorbed by newly established Vietnamese National Army (VNA).

Soon after taking up his post as commander-in-chief for CEFEO, General Jean de Lattre de Tassigny changed the force structure in Indochina. Where the inclusion of Binh Xuyen, Hoa Hao and Cao Dai into the Vietnamese National Army signified a process of regularization of formerly irregular auxiliaries, the de Lattre reforms aimed at increasing both regular forces in the framework of CEFEO and at creating new irregular auxiliaries or even to divert regular troops to irregular roles. De Lattre created the Commandos Nord Vietnam, which consisted of CEFEO troops, but had an irregular mission as raider units in the anti-guerrilla campaign against the Viet Minh. He also established the Groupement de Commandos Mixtes Aéroportés (GCMA), renamed in 1953 in Groupe Mixte d'Intervention. These were recruited from among the native population and initially trained and commanded by French officers. Their tasks were partly military and included small operations to harass the enemy and to carry out sabotage missions. However, more important was their mission to foster collaboration of the local population against the Viet Minh, both in French controlled and in Viet Minh territory. French commanders involved in the GCMA, many of whom had a background in the French résistance, referred to this task as the establishment of a local maquis. One of the junior officers involved in the GCMA, Lieutenant Pierre Dabezies argued that "in Indochina, the "native" side had to prevail over the technical side ... without native cooperation, it was almost impossible to infiltrate the population. Therefore, natives were often recruited more for their roots than for their skills. ${ }^{22}$ In other words, while their military value remained limited, the GCMA/GMI's primary task was to foster a loyalist network among the native population. However, their limited military prowess did not mean that they were exempt from Viet Minh violence. On the contrary, they often were its prime target. 
In the Malayan Emergency (1948-60), a wide variety of forces were deployed in the fight against the communist, Chinese-dominated insurgency mounted by the Malayan National Liberation Army (MNLA). In addition to British armed forces and other Commonwealth troops from Australia and New Zealand, Britain also deployed two battalions of the Royal Malay Regiment, seven Ghurka battalions and three King's African Rifles (KAR) battalions. Before the onset of the emergency Britain had attempted to raise a multi-communal 'Malayan army', which was supposed to include ethnic groups other than the majority Malays. However, this had failed owing to Malay resistance. ${ }^{23}$

Partly as a result of this failure, British initiatives of enlisting the Chinese community in the fight against the MNLA focused on the newly established auxiliary forces, the Home Guard. The Home Guard was mainly tasked with upholding the security of the New Villages. By 1952, the Home Guard numbered 250,000 and drew on both Malay and Chinese sections of the population. Neither Malay nor Chinese Home Guard units were seen as militarily highly effective. The British were particularly suspicious with respect to the Chinese Home Guards, who were initially even more poorly equipped than their Malay counterparts and were only given additional weapons as a reward once they had proven their loyalty. ${ }^{24}$

However, the real value of the Home Guard did not lie in their military effectiveness anyway. According to David French, 'Only partly trained and equipped with shotguns, their ratio of kills to contacts was the lowest of all elements of the security forces. But that hardly mattered. Their real importance was that they helped sustain the morale of Malaya's population in the face of insurgent intimidation, and forced the Chinese, however reluctantly, to side with the security forces.' 25 Conversely, the existence of the Home Guard sapped the insurgents' morale: 'The mere suspicion among the MNLA that Home Guard might give information hurt morale. ${ }^{26}$

In Kenya during the Mau Mau uprising, we see a similar picture of a variety of European, colonial and native auxiliary forces operating alongside each other. British army and Royal Air Force (RAF) deployed to Kenya in 1952, in addition to five KAR 
regiments. The Kenya Regiment, a settler militia, also took part in the security forces' combined operations. In addition, the colonial administration recruited native irregular auxiliaries shortly after the start of the uprising. Inspired by the Home Guard in Malaya, the Kenyan Home Guard was created in July 1952. By March 1954 it numbered 25,600 native Kikuyu loyalists. Even though the Home Guard was never formally incorporated in the military chain of command, it often found itself in the midst of the violent conflict between the Mau Mau and the British security forces. This also meant that Home Guard members were highly vulnerable to attacks. ${ }^{27}$ Unsurprisingly, the Home Guard became the victim of one of the most notorious atrocities of the Mau Mau uprising, the Lari massacre of 25 and 26 March 1953, in which Mau Mau killed between 74 and 100 members of the Home Guard and their families. $^{28}$

After the Lari massacre, the structure of the Home Guard was overhauled and settler officers took on command of individual Home Guard units. Its core mission gradually changed as well: while the Home Guard was initially designed as a selfdefense force, after 1953 it increasingly took an active part in the violence and was 'entrusted with counter-terror'. ${ }^{29}$ Indeed, according to David Anderson, doing the 'dirty work' of state counter-terror became the foremost task of the Home Guard: 'Using the Home Guard as surrogates, British officials ignored gross atrocities ... and contracted out interrogation and torture to their allies. ${ }^{30}$ However, the British valued counter-terror not primarily due to its military effectiveness. What was more important was the concomitant 'polarisation of the population, the swing towards loyalism, and the crystallization of a loyalist identity', which led to a more profound consolidation of the security situation in Kenya.

Finally, native Kikuyu were also recruited into so-called 'pseudo-gangs', a practice that has become associated with the name of the British officer Frank Kitson. Pseudo-gangs were dressed up as Mau Mau and were used in 1953 and 1954 to hunt down remaining Mau Mau in the Aberdare forest. While they were militarily rather effective, they did not have the same political value as the loyalist Home Guard. In fact, only few loyalists took part in the pseudo-gang operations, which were mostly manned by turned Mau Mau detainees. The latter did not act out of loyalist motives; 
rather, they were forced to join the pseudo-gangs in order to avoid being hanged for their participation in the uprising. ${ }^{31}$

In Algeria (1954-62), a similar picture emerged. The French army fought alongside ten North African tirailleur regiments. There was even a limited number of former tirailleurs from the Far East Commando involved. After the outbreak of the ALN revolt in 1954, the French colonial administration started recruiting local irregular auxiliaries. So-called moghnaznis were designated as local self-defence forces, while the harkis had the task of participating in anti-guerrilla operations. The latter far outnumbered the former throughout the conflict, and the term harkis was often used as a catch-all phrase for all sorts of native collaborators.

Initially, the recruitment of harkis followed a pattern familiar from earlier colonial times. In 1954 the French ethnologist Jean Servier raised harkis by exploiting the traditional conflicts among Berber tribes in the Aurès region. ${ }^{32}$ Mass mobilization of harkis only took off with the implementation of the Challe offensive between 1958 and 1960. During these years the number of harkis peaked at approximately 60,000, which meant that the harkis outnumbered ALN fighters.

In contrast to the regular colonial forces deployed in Algeria, harkis were hired on a daily basis, and their access to weapons was limited. ${ }^{33}$ In part, the recruitment of harkis was inspired by notions harkening back to the martial races discourse: 'Another assumption - explicit in some documents - was they [the harkis] had a specific form of violence, a native way of being violent that was adapted to a war against natives. ${ }^{34}$ However, even if the harkis, similar to the Home Guard in Kenya, were instrumentalized for counter-terror purposes, their military value was always limited, not least owing to their poor training and armament. Their political value in the form of their conspicuous 'loyalism' was far more important for the French colonial administration: "the harkis were presented as "Algerians fighting on the French side". As long as the war went on and the ALN lost more and more men, the French could claim that there were more Algerians on their side than on the ALN's. ${ }^{35}$ Indeed, the French were careful to depict the harkis as being driven by noble motivations and as having joined the French in their fight against the ALN deliberately, rather than being coerced into making opportunistic choices, which are 
typical for situations of irregular warfare. Similar to the French rhetoric in Indochina, General Challe insisted that the harkis should have 'a mentality of attacking maquisards and not one of collaborators. ... If we build heroes of the Résistance, the population will be on our side. ${ }^{36}$

The Vietnam War (1962-75) offers the most complex picture regarding the diversity of troops deployed to combat the Viet Cong and the North Vietnamese armed forces. In the course of the escalation of the conflict in 1965, US army and Marine Corps and Australian armed forces joined the Army of the Republic of Vietnam, which had been created after the partition of Vietnam in the 1954 Geneva accords, in its fight against the North and its communist insurgent allies.

South Vietnam had already created its own militia forces in 1955 in the wake of the Geneva accords, the Territorial Forces, later renamed Regional Forces (RF) and Popular Forces (PF). Originally tasked with local security and self-defence, RF/PF, known as 'Ruff-Puffs' among US officers, were primarily deployed in the framework of US 'pacificiation' programmes in Vietnam, such as the in the Marine-led Combined Action Programme (CAP) as well as in CORDS (Civil Operations and Revolutionary Development Support), which was established in 1967. Both the first head of CORDS, Robert Komer, and his successor after November 1968, William Colby, worked to increase the number of RF/PF forces. In 1969, they numbered 475,000. Even though RF/PF were poorly trained and armed, they absorbed a high degree of Viet Cong violence and suffered consistently higher casualty rates than the ARVN. Yet they remained underequipped throughout the conflict and often did not receive ARVN support when they requested it. ${ }^{37}$ However, both Andrew Krepinevich and Mark Moyar argue that the RF/PF were militarily effective in the decentralized campaign against the Viet Cong. ${ }^{38}$ Still, they remained dependent on support by regular troops: after the withdrawal of US forces $\mathrm{RF} / \mathrm{PF}$ units were integrated into the ARVN command structure, but destroyed during the fall of Saigon in 1975.

A second irregular auxiliary force were the Civilian Irregular Defense Groups (CIDG), which the CIA created as early as 1961. In 1963 command over CIDG was transferred from the CIA to Military Assistance Command, Vietnam (MAC-V). CIDG members were recruited from among the montagnard tribes of the central 
highlands of South Vietnam. The practice of raising montagnard tribes for counterinsurgency efforts went back to French colonial times. The highland mountain people were traditionally opposed to the Annamite majority in Vietnam. The initial purpose of CIDG was local defence and civic action in their native highland territories. However, they became increasingly highly trained and involved in military operations outside of their own areas in Special Forces (SF) roles. In 1970 they were formally integrated into the ARVN as SF Vietnam Army Ranger units.

Pseudo-gangs were also recruited in Vietnam in the form of the Provincial Reconnaissance Units (PRUs). The PRUs included many former Viet Cong who had been induced to switch sides in the framework of the Chieu Hoi ('open arms') programme. Their mission was the destruction of Viet Cong infrastructure within the framework of the controversial Phoenix programme. Phoenix was integrated into CORDS in 1967 and gathered momentum in 1968 and 1969, at a time when concerns over the moral costs of the Vietnam War became increasingly central in the wake of the My Lai massacre in March 1968. Even though the PRUs were seen as militarily effective, the US army's concerns over their practices grew. According to Dale Andrade, 'the JCS [Joint Chiefs of Staff] simply wanted someone else to do the dirty work'. ${ }^{39}$ As a result, the army withdrew its advisors from the PRUs in 1970 and Phoenix continued under the direction of the CIA until 1972.

Last but not least, in April 1968 the South Vietnamese government also started to raise a loyalist militia force, the People's Self-Defense Force. It counted 4 million members, but had only 600,000 weapons at its disposal. Again, its political value was much greater than its military effectiveness: 'Probably more important than any military capability presented by these forces was the overt commitment to the government represented by their participation., 40

The example of the Vietnam War illustrates how different types of auxiliaries could co-exist within the framework of one operational theatre. The variety of different auxiliary fighters as well as their evolving and fluctuating roles in large parts reflects the ambiguous strategic situation that the US forces faced in Vietnam. What is more important, however, is that the case of Vietnam highlights the comparative vulnerability of those auxiliary forces who resemble most closely the loyalist type as 
opposed to those who, like the CIDG, started out as partisans and later became regularized.

During the Dhofar rebellion (1963-76), a very limited number of British army and Special Air Service (SAS) troops, plus soldiers from the Imperial Iranian Armed Forces supported the Omani Sultan's Armed Forces (SAF) against Dhofari rebel groups. British troops were first deployed in 1970. Part of the renewed pacification effort under Sultan Qaboos after 1970 envisaged the recruitment of native tribal auxiliaries, so-called firqats. Their number grew from 300 in 1970 to 1,200 in 1974 . From the start, the role of the firqats was seen as essential in engendering loyalism in Dhofar: the firqats were 'an essential bridge between the Omani government and the Dhofari population' ${ }^{41}$ However, they were also used in military operations against the rebels. Yet, their military effectiveness soon proved extremely limited: 'The irregular firqats proved a disappointment. Each firqat mutinied at least once, they refused to serve in areas or with individuals not of their tribe, and their members frequently informed the enemy of their movements. Operations dependent on the firqats, such as Operation Jaguar or the attack on the Shershitti caves, failed. As Brigadier Graham observed, "They [the firqats] operate not as ordered, but as their own interests dictate. Thus, no firm military plan can be made to which their participation is indispensable." 42

The contribution the firqats made to military victory over the Dhofari insurgency has been a subject for debate ${ }^{43}$ What seems to be undisputed is that the firqats proved to be fickle allies at best, and that their support in combat could not be counted on, even if they performed better in intelligence roles and in securing areas cleared from rebels.

\section{Loyalism and the moral re-evaluation of the irregular auxiliary}

The examples of colonial and post-colonial warfare described above demonstrate the involvement of a variety of different types of armed forces in these conflicts. In Indochina, Malaya, Kenya and Algeria, colonial troops such as tirailleurs, Gurkha troops, KAR and Malay Regiment forces were deployed alongside metropolitan troops. The historical origins of their recruitment had in most cases been 
inspired by the nineteenth century 'martial races' discourse, but they had become increasingly regularized in the meantime. In Vietnam and Dhofar, and in the later stages of the Indochina War, western troops supported native regular armies (the ARVN, SAF and VNA respectively). In Malaya and Kenya, colonial troops (the KAR and the Malay Regiment respectively) formed the core of the emerging state armies after independence.

Some of the contemporary recruitment practices in the insurgencies outlined above seemed to follow historical frameworks and ideas. The French and British initiative during the Indochina war to recruit Binh Xuyen, Hoa Hao and Cao Dai fighters into the counterinsurgency effort is both reminiscent of the eighteenth century 'partisan' concept and of the 'martial races' approach to recruiting native auxiliaries. The recruitment of montagnard tribes into the CIDG during the Vietnam War effectively harkened back to the French colonial use of these tribes in the nineteenth century, hence echoing themes from the 'martial races' discourse. Finally, even though the recruitment and use of Kenyan Home Guards and Algerian harkis ostensibly corresponded more squarely with the loyalist framework, contemporaries' rhetoric and practices had some over and undertones of the martial races discourse too. The idea that native violence could only be matched by natives and that counterterror should hence be left to the natives straddles the boundaries of the loyalism framework and the martial races mindset.

The recruitment of natives into the counter-insurgency effort also displayed some similarities with the eighteenth century concept of the partisan as the tactical counterpart of regular armed forces. The most straightforward example in this respect is de Lattre's creation of the Commandos Nord Vietnam, which were recruited from the regular VNA in order to conduct raiding missions into north Vietnamese territory. However, the establishments of pseudo-gangs in Kenya and in Vietnam also partly served a similar tactical purpose in that they were established with the aim to 'mop up' remaining insurgents cells. Even though the fact that the members of the pseudogangs had ostensibly been 'turned', it was difficult to depict them as loyalists in the stricter sense of the term, as their commitment to the counter-insurgency effort was so obviously a result of coercion. 
The most striking development in the recruitment of native auxiliary fighters in insurgencies after 1945 is the rise of the intellectual and political framework of loyalism as the background for their recruitment. The GCMA/GMI in Indochina, the Home Guard in Malaya and Kenya, the harkis in Algeria, the RF/PF and the People's Self-Defense Force in Vietnam and the firqats in Dhofar all share similar traits: they were mostly insufficiently trained and armed and, as a result, had only limited military effect. ${ }^{44}$ Despite their vulnerability, loyalist auxiliaries were often left exposed in the midst of the conflict, in the villages and remote rural areas, as conspicuous defenders of the government's cause; however, with little to no military support. Ironically, the lack of weapons at the disposal of loyalist forces often seemed to stem from an inherent distrust of their very loyalty on the part of the colonial or post-colonial administrations, as was the case with the Chinese Home Guard in Malaya and the harkis in French Algeria. However, more important than suspicion regarding their loyalty as a factor for their poor armament and weak integration into military structures was that their purpose was not primarily military, but political. Even if their local knowledge could be beneficial for intelligence purposes and even if their 'native' way of fighting often seemed suited for the purposes of counter-terror, in none of the cases described above the colonial or post-colonial administrations made efforts to foster those capabilities by increasing military or intelligence training or by providing better equipment. The prime value of loyalist militias lay in their role as a symbol of the legitimacy of the colonial power's or the supported government's counter-insurgency efforts and political positions, and their purchase among the local population.

How did this novel template of recruiting native auxiliaries emerge? In order to understand this development, we have to analyse it in the broader framework of the history of irregular warfare and the concept of the irregular fighter. ${ }^{45}$ The moral coding of the irregular fighter, which up until the Second World War had been characterized by the paradoxical trends of his or her marginalization as 'bandits', 'brigands', 'rebels' or 'savages' on the one hand and their veneration (and regularization) as 'martial races' on the other, underwent a re-evaluation after the Second World War. The experience of the Second World War had demonstrated that irregular fighters, such as the numerous resistance groups fighting Nazi German and Imperial Japanese occupation could be morally vindicated. As a result, after the 
Second World War, it was increasing difficult to vilify insurgent groups simply on the basis of the irregular tactics that they used. The rise of international communism also meant that insurgents could more easily be labeled 'communist terrorists', which indicated that from a western perspective, it was not so much their way of fighting that was reprehensible, but their political - or, even worse religious, in the case of the Mau Mau - motives for taking up the fight.

It is revealing in this respect that in many cases the discourse of loyalism harkened back to the moral universe of the Second World War and to the resistance against totalitarian regimes. Loyalists were deliberately recruited as irregular native auxiliaries, and in contrast to their colonial predecessors such as the tirailleurs, Gurkhas, KAR and Malay Regiment, they did not undergo a process of regularization in the course of the counter-insurgencies outlined above. On the contrary, their irregularity was often depicted as the very symbol of their legitimacy: in Indochina, the GCMA/GMI were tasked with establishing a 'maquis' - a term that originated in the framework of the French résistance. In Algeria, General Challe explicitly mentioned the résistance as the appropriate mindset and moral ideal of the harkis.

What did this shift towards a loyalist framework of recruitment and organization of native auxiliaries mean for those who fought in them? The main effect was a potential perpetuation of their vulnerability into the post-conflict, post-colonial phase. Unsurprisingly, the fate of loyalist auxiliaries depended on the outcome of the conflict: in Malaya, Kenya and Dhofar, all of which were deemed a victory for the counter-insurgent side (albeit the outcome in Malaya and Kenya was decolonization, of course), former loyalist auxiliaries fared well and often rose to power positions in the post-colonial state, such as in Kenya. ${ }^{46}$ In those cases where the counter-insurgent side was defeated and the political authorities were formed from among the ranks of its former opponent, the fate of the former loyalists was much less favourable. In Indochina, as French forces withdrew from an increasing number of areas between 1950 and 1954, they knew that the loyalists would become the target of revenge attacks. Many loyalists begged the French officers to take them along and to protect them. It was a traumatic experience for the officers involved, and one that contributed to the revolt of parts of the French army in 1961 in Algeria, as it became clear that the harkis would face a similar fate after French withdrawal. ${ }^{47}$ And indeed, they did: an 
estimated 30,000 - 40,000 Algerian Muslim loyalists were killed in the wake of Algerian independence. ${ }^{48}$ Many harkis tried to flee to France; however, de Gaulle was adamant that they were not to be relocated. 'According to de Gaulle's cold calculus the harkis had to be sacrificed because unlike the settlers, they belonged to a separate culture and religion. ${ }^{49}$ In Vietnam, the Hue massacre of 1968, in which troops of the North Vietnamese Army and Viet Cong had killed an estimated 2,800 to 6,000 loyalists and civilians after battle of Hue, had spread fear among loyalists over their fate in the event of a communist victory. The widespread panic that accompanied the North Vietnamese advance and the fall of Saigon in 1975 was a manifestation of these fears, as was the hectic US evacuation of Saigon in April 1975. There were allegations that US embassy staff in Saigon failed to destroy the records of about 30,000 former members of the PRUs operating in the framework of the Phoenix programme. The records allegedly fell into the hands of the communists after they took over Saigon, and many former loyalists were allegedly killed. ${ }^{50}$

\section{Conclusion}

The preceding sections have traced the trajectory of western collaboration with native auxiliaries. They discussed three intellectual templates of the use of native auxiliaries: the eighteenth century model of auxiliary 'partisans' as tactical complements to regular armed forces; the nineteenth century transformation of the 'partisan' to the irregular guerrilla fighter and the concomitant rise of the 'martial races' discourse; and, finally, the post-1945 model of the loyalist auxiliary as a symbol of the political legitimacy of the counter-insurgent side in the wars of decolonization and post-colonial insurgencies.

Loyalist auxiliaries differed from their nineteenth and early twentieth century predecessors in that they were largely irregular and not integrated into formal military command structures. They were both poorly armed and poorly trained, which meant that their military contribution was limited. Even though they were sometimes entrusted with 'special' missions such as counter-terror, their true value was political rather than military, in that they signified broad popular support for the cause and the political agenda of the counter-insurgent side. The rise of the loyalist template after the end of the Second World War, the article has argued, was a result of the moral 
reappraisal of irregular fighters as morally vindicated 'resistance' fighters and liberators.

However, the article has also demonstrated that the use of auxiliaries in wars in the peripheries of the international system after 1945 was not limited to loyalist auxiliaries, even though their emergence was the most conspicuous trend in the postSecond World War context. Rather, some auxiliary formations such as the recruitment of montagnard tribes during the Vietnam War or the creation of the Commandos Nord Vietnam during the Indochina War ostensibly harkened back to earlier templates - the 'martial races' template and the 'partisan' template respectively. This leads us to the final question, which is to what extent the three templates have affected the recruitment of native auxiliaries in wars with western involvement in the twenty-first century?

In general, the recruitment of native auxiliaries and their potential regularization into national armed forces has not been an overwhelming success so far. The western-trained Afghan National Army continues to be beset by problems related to corruption, ethnic factionalism, poor training and poor leadership. In the spring of 2014, the Iraqi Army disintegrated under the pressure of advancing Islamic State (IS) militants. The anti-Gadhafi forces in Libya that were supposed to form a new Libyan government are currently on the verge of plunging the country into a new civil war. Of course, the West cannot be blamed for all of the arising problems - in many cases local factors played a larger role. However, often the way in which the West tries to integrate local forces into its own strategic plans seemed to follow mixed and unclear agendas and models. Antonio Giustozzi, for instance, has argued with regard to the problems besetting the ANA: 'From the very beginning the ANA was torn between two opposite concepts of its role, that is acting as the auxiliary indigenous force of an occupying power or becoming a central/'national' army, able to secure the monopoly of force for the government of Afghanistan and to serve its internal and foreign policy aims.' 51

The instances of the use of native auxiliaries in recent conflicts in which the West seemed to follow to some extent the template of loyalism provide a stark warning that the pitfalls of loyalist auxiliaries have not changed much over the past 
decades. The most relevant example in this respect is the way in which the US-led coalition in Iraq attempted to capitalize on the Anbar Awakening starting in 2006 and to formalize it subsequently in the framework of the Sons of Iraq (SOI) scheme. Initially hailed as a masterstroke of US COIN experts, it was seen as a central element of the US forces' efforts to turn the tide of the insurgency in Iraq. ${ }^{52}$ However, after the US withdrawal from Iraq, the Iraqi government under Nouri al-Maliki proved fickle in its approach to the SOI and ostensibly reneged on its commitment to integrate SOI fighters into the Iraqi security forces or the civilian administration. A US-run disarmament, demobilization and reintegration (DDR) programme focused on teaching former SOI fighters vocational skills had started before the withdrawal of the US forces, but was apparently not continued by the Iraqi government. ${ }^{53}$ Sidelined by the Shiite dominated government and repeatedly targeted by sectarian violence, many of the former SOI fighters reportedly joined IS in $2014 .{ }^{54}$ More recent reports indicate that at least one tribe that was central to the SOI scheme, Albu Nimr, became the target of a massacre carried out by IS forces in October 2014. ${ }^{55}$ Loyalists who cannot count on western military protection, it seems, face a stark choice: continue to fight or become the target of violence.

\section{Endnotes}

1 Daniel L Byman, 'Friends Like These: Counterinsurgency and the War on Terrorism', International Security, xxxi (2006), 79-115.

2 E.g. Robert M Cassidy, 'The Long Small War: Indigenous Forces for Counterinsurgency', Parameters xxxvi (Summer 2006), 47-62; Yoav Gortzak, 'Using Indigenous Forces in Counterinsurgency Operations: The French in Algeria, 19541962', Journal of Strategic Studies, xxxii (2009), 307-33.

${ }^{3}$ Geraint Hughes and Chris Tripodi, 'Anatomy of a Surrogate: Historical Precedents and Implications for Contemporary Counter-Insurgency and Counter-Terrorism', Small Wars \& Insurgencies, xx (2009), 1-35.

4 Antonio Giustozzi, 'Auxiliary Force or National Army? Afghanistan's "ANA" and the Counter-Insurgency Effort, 2002-2006', Small Wars \& Insurgencies, xviii (2007), 4567; Austin Long, 'The Anbar Awakening', Survival, 1 (2008), 67-94.

5 E.g. Beatrice Heuser, 'Small Wars in the Age of Clausewitz: The Watershed between Partisan War and People's War', Journal of Strategic Studies, xxxiii (2010), 139-62; 
Martin Rink, 'The Partisan's Metamorphosis: From Freelance Military Entrepreneur to German Freedom Fighter, 1740 to 1815', War in History, xvii (2010), 6-36. See also the recent special issue 'The Origins of Small Wars: From Special Operations to Ideological Insurgencies', Small Wars \& Insurgencies, xxv (2014).

6 Andrew Mumford, Proxy Warfare (Cambridge: Polity, 2013), 1. However, note that over time proxies can become auxiliaries and vice versa.

7 Hew Strachan, European Armies and the Conduct of War (London, 1983), 11f.

8 Walter Laqueur, 'The Origins of Guerrilla Doctrine', Journal of Contemporary History, x (1975), 341-82.

9 Heuser, 'Small Wars in the Age of Clausewitz', 142.

${ }^{10}$ Heuser, 'Small Wars in the Age of Clausewitz', 144.

11 Quoted in John Grenier, The First Way of War: American War Making on the Frontier, 1607-1814 (Cambridge, 2005), $126 f$.

${ }^{12}$ Heuser, 'Small Wars in the Age of Clausewitz'; Rink, 'The Partisan's Metamorphosis'.

13 This is a heavily condensed version of an argument laid out in greater detail in Sibylle Scheipers, Unlawful Combatants: A Genealogy of the Irregular Fighter (Oxford, 2015), chapter two.

14 Gavin Rand, "Martial Races" and "Imperial Subjects": Violence and Governance in Colonial India, 1857-1914', European Review of History, xiii (2006), 3.

15 Cf. David Omissi, “Martial Races”: Ethnicity and Security in Colonial India 18581939', War \& Society, ix (1991), 1-27.

16 Patrick Porter, Military Orientalism: Eastern War through Western Eyes (London, 2009), 42.

17 Cf. Heather Streets, Martial Races: The Military, Race and Masculinity in British Imperial Culture, 1857-1914 (Manchester, 2004), who argues that the British 'martial races' discourse had its roots in the practice of recruiting Highlanders into the British armed forces.

18 Charles Mangin quoted in Joe Lunn, "Les Races Guerrière": Racial Preconceptions in the French Military about West African Soldiers during the First World War', Journal of Contemporary History, xxxiv (1999), 521. 'La Force Noire' was the title of a book Mangin published in 1910.

19 Raffael Scheck, Hitler's African Victims: The German Army Massacres of Black French Soldiers in 1940 (Cambridge, 2006). 
David French, The British Way in Counter-Insurgency, 1945-1967 (Oxford, 2011), 187.

21 The purpose of this section is not to establish causal factors for the creation of loyalist auxiliaries, in which case a different approach to case selection would have to be taken. Rather, the aim is to trace how the use of native auxiliary forces changed over time and how this change can be understood against the background of broader changes in the perception of irregular warfare.

${ }^{22}$ Philippe Pottier, 'GCMA/GMI: A French Experience in Counterinsurgency during the French Indochina War', Small Wars \& Insurgencies, xvi (2005), 132.

${ }^{23}$ Karl Hack, 'Imperialism and Decolonisation in Southeast Asia', in Karl Hack and Tobias Rettig (eds.), Colonial Armies in Southeast Asia (London, 2009), 257f.

24 Kumar Ramakrishna, Emergency Propaganda: The Winning of Malayan Hearts and Minds, 1948-1958 (Surrey, 2002), 168.

${ }^{25}$ French, British Way in Counter-Insurgency, 187.

${ }^{26}$ Karl Hack, 'Everyone Lived in Fear: Malaya and the British Way of CounterInsurgency', Small Wars \& Insurgencies, xxiii (2012), 688.

27 David Anderson, 'Surrogates of the State: Collaboration and Atrocity in Kenya's Mau Mau War', in George Kassimeris (ed.), The Barbarisation of Warfare (London, 2006), 162.

28 Daniel Branch, Defeating Mau Mau, Creating Kenya: Counterinsurgency, Civil War and Decolonization (Cambridge, 2009), 56.

29 Branch, Defeating the Mau Mau, 80.

30 Anderson, 'Surrogates of the State', 174.

31 David Anderson, Histories of the Hanged: Britain's Dirty War in Kenya and the End of Empire (London, 2005), 186.

32 Martin Evans, 'The Harkis: The Experience and Memory of France's Muslim Auxiliaries', in Martin S Alexander, Martin Evans and J F V Keiger (eds) The Algerian War and the French Army (Basingstoke, 2002), 21.

33 Raphaëlle Branche, 'Harkis in French Algeria', paper prepared for the workshop "'Staying True to Their Salt": The Recruitment and Management of Non-Western Personnel in Intelligence Services and Armed Forces, c. 1900-2010', Oxford, February 2010, 5f.

34 Branche, 'Harkis in French Algeria', 9.

35 Branche, 'Harkis in French Algeria', 11. 
36 Quoted in Branche, 'Harkis in French Algeria', 8.

37 Andrew Krepinevich, The Army and Vietnam (Baltimore, MD, 1986), 221.

38 Krepinevich, The Army and Vietnam, 221; Mark Moyar, Phoenix and the Birds of Prey: Counterinsurgency and Counterterrorism in Vietnam (Lincoln NE, 2007), 160.

39 Dale Andrade, Ashes to Ashes: The Rise and Demise of the Phoenix Program (New York, 1990), 184.

${ }^{40}$ Lewis Sorley, 'Vietnam's Better War', Orbis, lvii (2013), 524.

41 Marc DeVore, 'A More Complex and Conventional Victory: Revisiting the Dhofar Counterinsurgency, 1963-1974', Small Wars \& Insurgencies, xxiii (2012), 152.

42 DeVore, 'A More Complex and Conventional Victory', 166.

43 Cf. DeVore, 'A More Complex and Conventional Victory'; Walter C. Ladwig III, 'Supporting Allies in Counterinsurgency: Britain and the Dhofar Rebellion', Small Wars \& Insurgencies xix (2008), 62-88.

44 Except for the RF/PF, who were, according to Krepinevich, highly effective in spite of their poor circumstances. Krepinevich, The Army in Vietnam, 221.

45 See Scheipers, Unlawful Combatants, chapter five, for more details. See, however, also Fabian Klose, Human Rights in the Shadow of Colonial Violence: The Wars of Independence in Kenya and Algeria (Philadelphia, 2013) for a more skeptical perspective on the impact of the Second World War.

46 Branch, Defeating Mau Mau, 218.

47 Alexander J Zervoudakis, 'From Indochina to Algeria: Counter-Insurgency Lessons', in Martin S. Alexander, Martin Evans and J V F Keiger (eds.) The Algerian War and the French Army: Experiences, Images, Testimonies (Basingstoke, 2002), 43-60.

48 Evans, 'The Harkis', 127, gives a much higher estimate of 70,000-150,000 harkis assassinated after the cease-fire. However, there is not enough evidence to support this. Cf. Branche, 'Harkis in French Algeria'.

49 Evans, 'The Harkis', 127.

50 Le Thi Anh, 'The New Vietnam', National Review, 29 April 1977.

51 Giustozzi, ‘Auxiliary Force or National Army?’, 48.

52 Stephen Biddle, Jeffrey A. Friedman and Jacob N. Shapiro, 'Testing the Surge: Why Did Violence Decline in Iraq in 2007?', International Security, xxxvii (2012), 7-40. 
53 Anthony H. Cordesman and Sam Khazai, Iraq after US Withdrawal: US Policy and the Iraqi Search for Security and Stability (Washington, DC, 2012), 61.

54 E.g. Stephanie Sanok Kostro and Garrett Riba, 'Resurgence of al Qada in Iraq: Effect on Security and Political Stability', Center for Strategic and International Studies, 4 March 2014, http://csis.org/publication/resurgence-al-qaeda-iraq-effect-security-andpolitical-stability.

55 Ben Hubbard, 'Sunni Tribesmen Say ISIS Exacts Brutal Revenge', New York Times, 30 Oct. 2014. 